\title{
Increasing intakes of iron reduce status, absorption and biliary excretion of copper in rats
}

\author{
BY SHIGUANG YU ${ }^{1,2}$, CLIVE E. WEST ${ }^{1}$ AND ANTON C. BEYNEN ${ }^{1,2 *}$ \\ ${ }^{1}$ Department of Human Nutrition, Wageningen Agricultural University, PO Box 8129, \\ $6700 \mathrm{EV}$ Wageningen, The Netherlands \\ ${ }^{2}$ Department of Large Animal Medicine and Nutrition, Faculty of Veterinary Medicine, \\ Utrecht University, PO Box 80.157, 3508 TD Utrecht, The Netherlands
}

(Received 17 May 1993 - Revised 25 August 1993 - Accepted 23 September 1993)

\begin{abstract}
High intakes of Fe may impair Cu status, but the underlying mechanism is not known. Male rats, aged 7 weeks, were given purified diets adequate in $\mathrm{Cu}(8 \mathrm{mg} \mathrm{Cu} / \mathrm{kg})$ and containing either 7,40 or $389 \mathrm{mg}$ $\mathrm{Fe} / \mathrm{kg}$. After 6 weeks the concentrations of $\mathrm{Fe}$ in liver and spleen were positively related with dietary $\mathrm{Fe}$ level and those of $\mathrm{Cu}$ were negatively related with dietary $\mathrm{Fe}$ level. Increasing $\mathrm{Fe}$ intakes reduced apparent absorption and biliary excretion of $\mathrm{Cu}$ in a dose-dependent fashion. In individual rats, biliary $\mathrm{Cu}$ excretion showed a significant, positive correlation with liver $\mathrm{Cu}$ concentration. It is concluded that increased $\mathrm{Fe}$ intakes depress $\mathrm{Cu}$ absorption which produces a decrease in plasma and organ $\mathrm{Cu}$ concentrations. As a result, biliary $\mathrm{Cu}$ excretion is lowered which contributes to achieving $\mathrm{Cu}$ balance at high Fe intakes. Because the concentrations of $\mathrm{Cu}$ in plasma and bile, and also plasma ceruloplasmin $(E C$ 1.16.3.1) activities, showed much greater percentage reductions with increasing Fe intake than did the concentrations of $\mathrm{Cu}$ in organs, it is possible that increased Fe status interferes with the mobilization of $\mathrm{Cu}$ stores.
\end{abstract}

Iron: Copper: Absorption: Biliary excretion

Iron-deficiency anaemia is a global nutritional problem in children and pregnant women. One measure to fight this condition is Fe fortification of foods. In livestock production the feeding of supplemental $\mathrm{Fe}$ is common practice. The benefit of $\mathrm{Fe}$ supplements in preventing anaemia is well recognized, but the potential negative effects, if any, have been less well studied.

High intakes of $\mathrm{Fe}$ have been shown adversely to affect $\mathrm{Cu}$ status in ruminants (Standish et al. 1969; Humphries et al. 1983), guinea-pigs (Smith \& Bidlack, 1980) and rats (Bremner \& Young, 1981; Bremner et al. 1982; Bremner \& Price, 1985; Johnson \& Hove, 1986). It is not yet clear how extra dietary $\mathrm{Fe}$ alters plasma and tissue $\mathrm{Cu}$ concentrations in animals. Bremner \& Young (1981) suggested that intake of excess Fe stimulates excretion of stored $\mathrm{Cu}$. If $\mathrm{Cu}$ balance is attained after Fe feeding, the suggestion of Bremner \& Young (1981) implies that increased intake of dietary $\mathrm{Fe}$, at least as a secondary effect, would enhance $\mathrm{Cu}$ absorption. In feeding trials with rats given $\mathrm{Cu}$-adequate diets for up to $20 \mathrm{~d}$, dietary $\mathrm{Fe}$ concentrations ranging from about 35 to $500 \mathrm{mg} / \mathrm{kg}$ have been shown not to affect apparent Cu absorption (Johnson \& Hove, 1986; Johnson \& Murphy, 1988; ReichlmayerLais \& Kirchgessner, 1992).

$\mathrm{Cu}$ balance in rats is determined essentially by the efficiency of $\mathrm{Cu}$ absorption and by the faecal loss of endogenous $\mathrm{Cu}$, essentially representing the unabsorbed fraction of $\mathrm{Cu}$ excreted with bile (Van den Berg \& Beynen, 1992). We hypothesized that the impaired $\mathrm{Cu}$

\footnotetext{
* For reprints.
} 
status seen after Fe loading is due either to diminished $\mathrm{Cu}$ absorption followed by a decrease in biliary $\mathrm{Cu}$ excretion or to enhanced biliary $\mathrm{Cu}$ excretion with an increase in $\mathrm{Cu}$ absorption as a secondary feature. The two possibilities were examined in a 6-week trial using rats given $\mathrm{Cu}$-adequate diets containing either low, normal or high amounts of $\mathrm{Fe}$.

\section{MATERIALS AND METHODS}

The protocol of the experiment was approved and its conduct supervised by the Animal Welfare Officer of the Wageningen Agricultural University.

\section{Animals and diets}

Male Wistar rats ( $\mathrm{Hsd} / \mathrm{Cpb}: \mathrm{WU})$ aged about 7 weeks were used. On arrival they were housed in groups of five in stainless steel cages $(600 \times 210 \times 190 \mathrm{~mm})$ with wire mesh bases and given the purified diet containing $40 \mathrm{mg} \mathrm{Fe} / \mathrm{kg}$ (Table 1) and demineralized water ad lib. for $10 \mathrm{~d}$. Then (day 0 of the experiment) the rats were divided into three groups of fifteen rats each, stratified for body weight and blood haemoglobin concentration. The groups were randomly allocated to one of the experimental diets, each of which contained an adequate amount of $\mathrm{Cu}(8 \mathrm{mg} / \mathrm{kg})$. One group remained on the diet containing $40 \mathrm{mg}$ $\mathrm{Fe} / \mathrm{kg}$, and the other groups were transferred to the diets containing either 7 or $389 \mathrm{mg}$ $\mathrm{Fe} / \mathrm{kg}$. Table 1 shows the ingredient composition of the diets which only differed with regard to Fe concentration. Fe was added to the diets in the form of $\mathrm{FeSO}_{4} \cdot 7 \mathrm{H}_{2} \mathrm{O}$. The diet with $40 \mathrm{mg} \mathrm{Fe} / \mathrm{kg}$ was formulated according to the recommended nutrient requirements of rats (National Research Council, 1978). The diets were stored at $4^{\circ}$ until feeding. The rats had free access to the experimental diets and demineralized water. As from day 0 of the experiment the rats were housed individually in stainless steel cages $(240 \times 170 \times 170 \mathrm{~mm})$ in a room with controlled lighting (light on: 06.00-18.00 hours), temperature (19-21 $)$ and relative humidity $(50-60 \%)$. Feed intake and body weight were recorded.

\section{Collection of samples}

Blood samples were taken at weeks $0,2,4$ and 6 . For the first three time points the rats, while in the fed state, were subjected to orbital puncture while they were under light diethylether anaesthesia, and blood samples were collected in heparinized tubes. Faeces were collected quantitatively during the last $4 \mathrm{~d}$ of the experiment.

At the end of the experiment in week 6 , bile was collected by common bile duct cannulation with polyethylene tubing $(0.28 \mathrm{~mm}$ i.d., $0.61 \mathrm{~mm}$ o.d.; Intramedic; Clay Adams, Parsippary, NJ, USA). The abdomen was opened while the rats were under anaesthesia induced by a combination of ketamine $(60 \mathrm{mg} / \mathrm{kg}$ body weight $)$ administered intramuscularly and xylazine $(8 \mathrm{mg} / \mathrm{kg}$ body weight) administered subcutaneously. This combination of the two drugs was used since it has been shown not to influence bile flow in rats (Fleck \& Barth, 1990). After the cannula was inserted into the common bile duct and secured with suture thread, the rats were kept on a heating pad $\left(36-38^{\circ}\right)$. Bile was collected into pre-weighed vials for three consecutive periods of 15,30 and $30 \mathrm{~min}$, and the volume of bile was calculated from the weight and specific gravity of bile. Bile samples were stored at $-20^{\circ}$ until analysis.

Following bile collection, blood samples were taken from the anaesthetized rats by abdominal aorta puncture. The rats were then killed by decapitation and liver, spleen, kidneys, heart and left tibia were removed, weighed and stored at $-20^{\circ}$ until analysis.

\section{Analytical methods}

Haemoglobin concentration and packed cell volume of fresh, heparinized blood samples were measured by using the Sysmex K-1000D (Sysmex-TOA; TOA Medical Electronics 
Table 1. Composition of the experimental diets

\begin{tabular}{|c|c|c|c|}
\hline Diet... & Low-Fe & Normal-Fe & High-Fe \\
\hline \multicolumn{4}{|l|}{ Ingredients } \\
\hline Constant components* $(\mathrm{g})$ & $290 \cdot 6$ & $290 \cdot 6$ & $290 \cdot 6$ \\
\hline Glucose $(\mathrm{g})$ & $709 \cdot 4$ & $709 \cdot 2$ & 707.7 \\
\hline $\mathrm{FeSO}_{4} .7 \mathrm{H}_{2} \mathrm{O}(\mathrm{mg})$ & 0 & 174 & 1740 \\
\hline \multicolumn{4}{|l|}{ Chemical analysis } \\
\hline $\mathrm{Fe}(\mathrm{mg})$ & 6.8 & $40 \cdot 2$ & 388.8 \\
\hline $\mathrm{Cu}(\mathrm{mg})$ & $8 \cdot 1$ & $8 \cdot 1$ & $8 \cdot 1$ \\
\hline
\end{tabular}

* The constant components consisted of $(\mathrm{g} / \mathrm{kg}$ diet $)$ : casein 151 , maize oil 25 , coconut oil 25 , cellulose 30 , $\mathrm{CaCO}_{3} 12 \cdot 4, \mathrm{NaH}_{2} \mathrm{PO}_{4} \cdot 2 \mathrm{H}_{2} \mathrm{O} 15 \cdot 1, \mathrm{MgCO}_{3} 1 \cdot 4, \mathrm{KCl} 1 \cdot 0, \mathrm{KHCO}_{3} 7 \cdot 7$, mineral premix 10, and vitamin premix 12. The Fe-free mineral premix consisted of (mg/kg feed): $\mathrm{MnO}_{2} 79, \mathrm{ZnSO}_{4}, \mathrm{H}_{2} \mathrm{O} 33, \mathrm{NiSO}_{4} \cdot 6 \mathrm{H}_{2} \mathrm{O} 13, \mathrm{NaF} 2, \mathrm{KI}$ $0.2, \mathrm{CuSO}_{4} .5 \mathrm{H}_{2} \mathrm{O} 15 \cdot 7, \mathrm{Na}_{2} \mathrm{SeO}_{3} .5 \mathrm{H}_{2} \mathrm{O} 0 \cdot 3, \mathrm{CrCl}_{3} .6 \mathrm{H}_{2} \mathrm{O} 1 \cdot 5, \mathrm{SnCl}_{2} .2 \mathrm{H}_{2} \mathrm{O} 1 \cdot 9, \mathrm{NH}_{4} \mathrm{VO}_{3} 0.2$ and maize meal 9853.2. The vitamin premix consisted of $(\mathrm{mg} / \mathrm{kg}$ feed): thiamin 4 , riboflavin 3, nicotinamide 20 , DL-calcium pantothenate 17.8 , pyridoxine 6 , cyanocobalamin 50 , choline chloride 2000 , pteroylmonoglutamic acid 1 , biotin 2 , menadione $0 \cdot 05$, DL- $\alpha$-tocopheryl acetate 60 , retinyl acetate and retinyl palmitate 8 (1200 retinol equivalents), cholecalciferol 0.025 , maize meal $9828 \cdot 125$.

Co. Ltd, Kobe, Japan). The concentration of $\mathrm{Fe}$ and $\mathrm{Cu}$ in organs, faeces and feed was determined by flame atomic absorption spectrometry (Varian AA-475; Varian Techtron, Springvale, Australia). For the determination of $\mathrm{Cu}$ and $\mathrm{Fe}$ in organs and feed, samples were dried in a vacuum dryer for $48 \mathrm{~h}$ and digested in $1.0 \mathrm{ml} 14 \mathrm{M}-\mathrm{HNO}_{3}$ (Suprapur; Merck, Darmstadt, Germany) at $80^{\circ}$ for $2 \mathrm{~h}$. Samples of faeces were first dried, ashed at $500^{\circ}$ for $17 \mathrm{~h}$ in a muffle furnace and then dissolved in $6 \mathrm{M}-\mathrm{HCl}$. Cu in plasma was measured directly.

$\mathrm{Fe}$ and total Fe-binding capacity in plasma were determined using a commercial reagent kit (Iron FZ Test, Roche; Roche Diagnostics, Basel, Switzerland) and a Cobas-Bio autoanalyser (Hoffmann-La Roche BV, Mijdrecht, The Netherlands). The determination of $\mathrm{Cu}$ and $\mathrm{Fe}$ in bile was carried out using flameless atomic absorption spectrometry (Varian AA-300) after dilution of the samples with demineralized water. An external control in the form of a bovine liver sample (NBS 1577a; National Institute of Standards Technology, Gaithersburg, MD, USA) was used to assess bias of $\mathrm{Fe}$ and $\mathrm{Cu}$ analysis. Analysed $\mathrm{Fe}$ and $\mathrm{Cu}$ concentrations were 105.3 (SE 4.03)\% (n 6) and 98.7 (SE 4.61)\% ( 6 ) of the target values respectively. Ceruloplasmin $(E C 1.16 .3 .1)$ in plasma was assayed as $p$-phenylenediamine oxidase $(E C 1,16.3 .1)$ activity as described by Sunderman \& Nomoto (1970).

\section{Statistical analyses}

The data were subjected to one-way analysis of variance and a multiple comparison test (Tukey test). The data for bile flow and biliary $\mathrm{Fe}$ and $\mathrm{Cu}$ concentrations were analysed using two-way analysis of variance. The level of significance was pre-set at $P<0.05$. All data were analysed using a computer program (SPSS Inc., 1988).

\section{RESULTS}

Feed intake, body and organ weights

The concentration of $\mathrm{Fe}$ in the diet had no significant effect on feed intake or body weight of the rats (Table 2). Likewise, there were no group differences in the weights of spleen and heart. Liver and kidney weights in the low-Fe group were significantly lower than those in 
Table 2. Feed intake and body and organ weights of rats fed on experimental diets containing low, normal or high amounts of iron*

(Mean values for fifteen rats per dietary group)

\begin{tabular}{|c|c|c|c|c|}
\hline Diet... & Low-Fe & Normal-Fe & High-Fe & Pooled SE \\
\hline \multicolumn{5}{|l|}{ Body weight (g) } \\
\hline Initial & $192 \cdot 4$ & 191.4 & $192 \cdot 7$ & 3.96 \\
\hline Final & 353.9 & $360 \cdot 1$ & $352 \cdot 8$ & 6.43 \\
\hline \multicolumn{5}{|l|}{ Feed intake $(g / d)$} \\
\hline Week 1 & $20 \cdot 5$ & $21 \cdot 6$ & $21 \cdot 5$ & 0.40 \\
\hline Week 6 & $19 \cdot 9$ & $20 \cdot 9$ & $20 \cdot 7$ & 0.34 \\
\hline \multicolumn{5}{|c|}{ Organ wt (g/kg body wt) } \\
\hline Liver & $34 \cdot 5^{\mathrm{a}}$ & $37 \cdot 2^{b}$ & $37 \cdot 8^{\mathrm{b}}$ & 0.57 \\
\hline Spleen & $2 \cdot 3$ & $2 \cdot 1$ & $2 \cdot 2$ & 0.08 \\
\hline Kidney & $5 \cdot 8^{2}$ & $6 \cdot 0^{\mathrm{ab}}$ & $6 \cdot 3^{b}$ & $0 \cdot 15$ \\
\hline Heart & $3 \cdot 4$ & $3 \cdot 3$ & $3 \cdot 4$ & 0.09 \\
\hline
\end{tabular}

a.b Means in the same row with unlike superscript letters were significantly different $(P<0.05)$.

* For details of diets and procedures, see Table 1 and pp. 888-889.
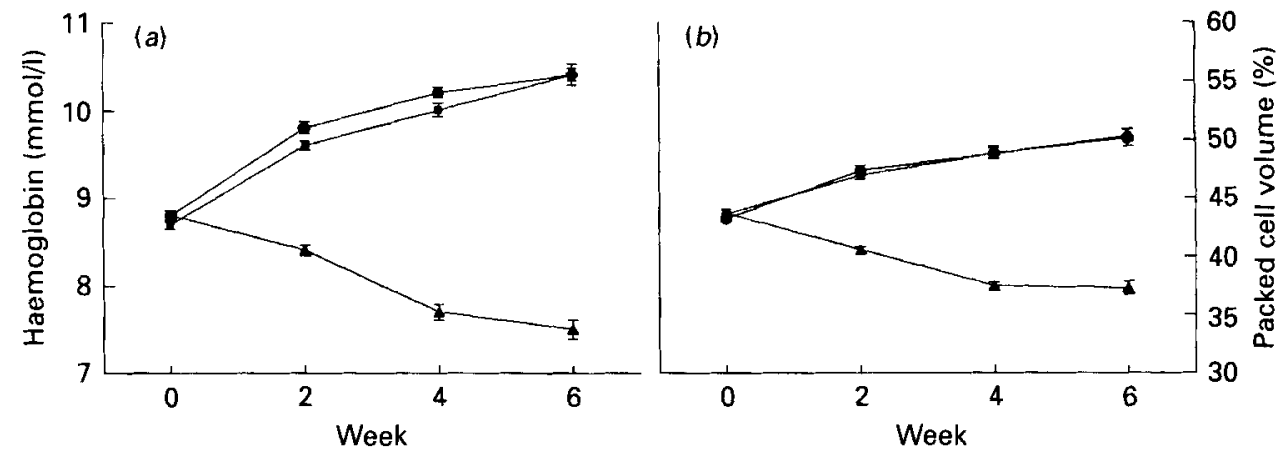

Fig. 1. Time course of blood haemoglobin concentrations $(a)$ and packed cell volume $(b)$ in rats fed on either a low- $(\mathbf{\Delta})$, normal- $(\boldsymbol{\square})$ or high-( $(\boldsymbol{O})$ Fe diet. There were significant effects of diet $(P<0.05)$ for both haemoglobin (pooled SE $0.022 \mathrm{mmol} / \mathrm{l}$ ) and packed cell volume (pooled SE $0.767 \%$ ). For details of diets and procedures, see Table 1 and pp. 888-889.

the high-Fe group. Liver weight of the low-Fe group was also lower than that of the normal-Fe group.

\section{Indicators of iron status}

Fig. 1 shows that blood haemoglobin concentrations and packed cell volume decreased in the rats given the low-Fe diet, whereas in the other two groups there was a similar rise with time. After 6 weeks, Fe concentrations in all organs and plasma were significantly lower in rats fed on the low-Fe diet compared with those fed on the normal-Fe diet (Table 3). Rats given the high-Fe instead of the normal-Fe diet displayed significantly higher values except for kidney, heart and plasma. Total Fe-binding capacity was similar in rats fed on the normal and high-Fe diets $(1.6$ and $1.5 \mathrm{mmol} / 1)$, but was significantly raised $(P<0.05)$ in their counterparts given the low-Fe diet $(2 \cdot 1 \mathrm{mmol} / 1$, pooled SE $0.03 \mathrm{mmol} / \mathrm{l})$. 
Table 3. Organ and plasma iron concentrations in rats fed on experimental diets containing low, normal or high amounts of iron*

(Mean values for fifteen rats per dietary group)

\begin{tabular}{lcccc}
\hline Diet ... & Low-Fe & Normal-Fe & High-Fe & Pooled SE \\
\hline Organ Fe (mmol/kg) $\dagger$ & & & & \\
$\quad$ Liver & $3 \cdot 3^{\mathrm{a}}$ & $7 \cdot 6^{\mathrm{b}}$ & $9 \cdot 8^{\mathrm{c}}$ & 0.32 \\
Spleen & $19 \cdot 1^{\mathrm{a}}$ & $46 \cdot 3^{\mathrm{b}}$ & $55 \cdot 9^{\mathrm{a}}$ & $1 \cdot 72$ \\
Kidney & $3 \cdot 4^{\mathrm{a}}$ & $5 \cdot 2^{\mathrm{b}}$ & $5 \cdot 4^{\mathrm{b}}$ & $0 \cdot 17$ \\
Heart & $4 \cdot 8^{\mathrm{a}}$ & $6 \cdot 3^{\mathrm{b}}$ & $6 \cdot 4^{\mathrm{b}}$ & $0 \cdot 15$ \\
Tibia & $0 \cdot 75^{\mathrm{a}}$ & $1.57^{\mathrm{b}}$ & $1 \cdot 77^{\mathrm{c}}$ & $0 \cdot 052$ \\
Plasma Fe (mmol/1) & $0 \cdot 19^{\mathrm{a}}$ & $0.55^{\mathrm{b}}$ & $0 \cdot 56^{\mathrm{b}}$ & $0 \cdot 019$ \\
\hline
\end{tabular}

a, b.c Means in the same row with unlike superscript letters were significantly different $(P<0 \cdot 05)$.

$\dagger$ On a dry-weight basis.

* For details of diets and procedures, see Table 1 and pp. 888-889.

Table 4. Organ and plasma copper concentrations and plasma ceruloplasmin (EC 1.16.3.1) concentrations in rats fed on experimental diets containing low, normal or high concentrations of iron*

(Mean values for fifteen rats per dietary group)

\begin{tabular}{|c|c|c|c|c|}
\hline Diet. & Low-Fe & Normal-Fe & High-Fe & Pooled SE \\
\hline \multicolumn{5}{|l|}{ Organ $\mathrm{Cu}(\mathrm{mmol} / \mathrm{kg}) \dagger$} \\
\hline Liver & $0 \cdot 28^{\mathrm{a}}$ & $0 \cdot 26^{\mathrm{b}}$ & $0 \cdot 23^{\mathrm{b}}$ & 0.008 \\
\hline Spleen & $0 \cdot 17^{\mathbf{a}}$ & $0 \cdot 15^{\mathrm{ab}}$ & $0 \cdot 12^{\mathrm{b}}$ & $0 \cdot 011$ \\
\hline Kidney & $0 \cdot 40^{\mathrm{a}}$ & $0 \cdot 43^{\mathrm{a}}$ & $0 \cdot 31^{\mathrm{b}}$ & $0 \cdot 014$ \\
\hline Heart & $0 \cdot 42^{\mathrm{a}}$ & $0 \cdot 41^{\mathrm{a}}$ & $0 \cdot 39^{\mathrm{b}}$ & $0 \cdot 058$ \\
\hline Tibia & 0.08 & $0 \cdot 08$ & $0 \cdot 08$ & $0 \cdot 046$ \\
\hline \multicolumn{5}{|l|}{ Plasma } \\
\hline $\mathrm{Cu}(\mu \mathrm{mol} / 1)$ & $23 \cdot 6^{\mathrm{a}}$ & $22 \cdot 0^{\mathrm{a}}$ & $15 \cdot 7^{\mathrm{h}}$ & $1 \cdot 10$ \\
\hline Ceruloplasmin ( $\Delta$ absorption $/ 1$ per $\min$ ) & $144 \cdot 1^{\mathrm{a}}$ & $159 \cdot 9^{\mathrm{a}}$ & $85 \cdot 9^{b}$ & $10 \cdot 05$ \\
\hline
\end{tabular}

a. b Means in the same row with unlike superscript letters were significantly different $(P<0-05)$.

+ On a dry-weight basis.

* For details of diets and procedures, see Table 1 and pp. 888-889.

\section{Indicators of copper status}

The concentration of $\mathrm{Cu}$ in kidneys, heart and plasma as well as the ceruloplasmin activity was lower in the high-Fe group compared with the normal-Fe group while the $\mathrm{Cu}$ concentrations in liver were raised significantly in the low-Fe group (Table 4).

\section{Apparent copper absorption}

Increasing dietary Fe concentrations significantly reduced apparent $\mathrm{Cu}$ absorption (Fig. 2).

\section{Biliary iron and copper excretion}

Bile flow in the cannulated rats decreased with time, but there was no effect of dietary Fe concentration (Table 5). The concentration of $\mathrm{Fe}$ in bile was slightly, but significantly, reduced in rats fed on the low-Fe diet. With time there was an increase in biliary $\mathrm{Fe}$ concentration. The concentration of $\mathrm{Cu}$ was not determined in the initial 15 min sample of bile collected because the quantity of fluid obtained was insufficient. For the other two 


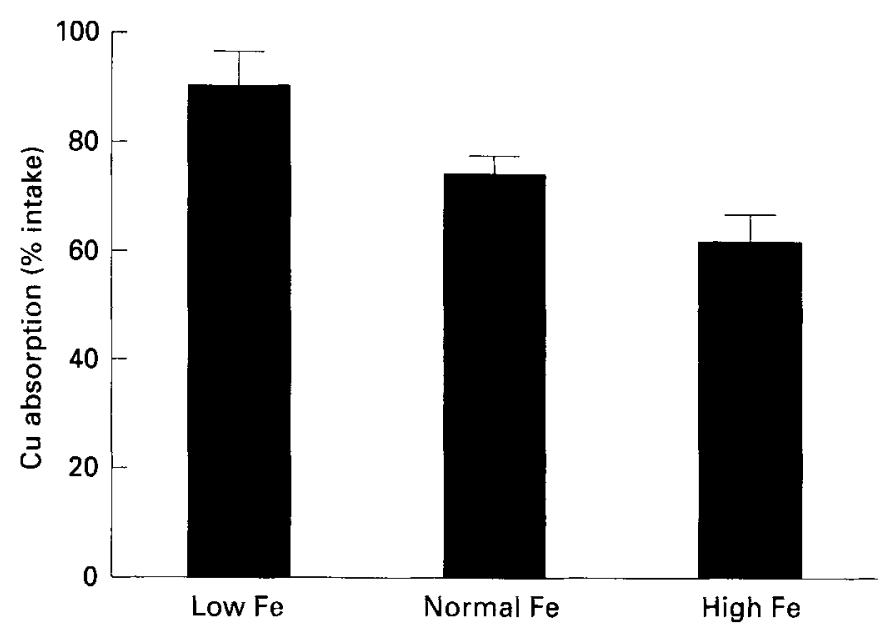

Fig. 2. Influence of experimental diets containing low, normal or high amounts of $F e$ on apparent Cu absorption in rats. Results are expressed as means and SE $(n 15)$ and were significantly different $(P<0.05)$ between dietary groups. For details of diets and procedures, see Table 1 and pp. 888-889.

Table 5. Bile flow and biliary iron and copper concentrations in rats fed on experimental diets containing low, normal or high amounts of iron*

(Mean values for fifteen rats per dietary group)

\begin{tabular}{|c|c|c|c|c|c|}
\hline Diet... & Low-Fe & Normal-Fe & High-Fe & Pooled SE & $\begin{array}{l}\text { Statistical } \\
\text { significance of } \\
\text { effects of }:^{\dagger}\end{array}$ \\
\hline \multicolumn{6}{|c|}{$\begin{array}{l}\text { Bile flow } \\
\text { (ml/kg body wt per h) }\end{array}$} \\
\hline $0-15 \mathrm{~min}$ & $2 \cdot 7$ & $3 \cdot 0$ & $2 \cdot 9$ & & \\
\hline $15-45 \mathrm{~min}$ & $2 \cdot 6$ & 2.7 & $2 \cdot 6$ & & \\
\hline $45-75 \mathrm{~min}$ & $2 \cdot 6$ & $2 \cdot 5$ & $2 \cdot 4$ & $0 \cdot 14$ & $\mathrm{P}$ \\
\hline \multicolumn{6}{|c|}{$\begin{array}{l}\text { Biliary Fe concentration } \\
(\mu \mathrm{mol} / \mathrm{l})\end{array}$} \\
\hline $0-15 \mathrm{~min}$ & 22 & 25 & 24 & & \\
\hline $1545 \mathrm{~min}$ & 25 & 29 & 30 & & \\
\hline $45-75 \mathrm{~min}$ & 28 & 34 & 34 & 1.9 & $\mathrm{Fe} ; \mathrm{P}$ \\
\hline \multicolumn{6}{|c|}{$\begin{array}{l}\text { Biliary Cu concentration } \\
(\mu \mathrm{mol} / 1)\end{array}$} \\
\hline $15-45 \mathrm{~min}$ & $19 \cdot 4^{a}$ & $12 \cdot 3^{b}$ & $1 \cdot 9^{\circ}$ & & \\
\hline $45-75 \mathrm{~min}$ & $19 \cdot 5^{\mathrm{a}}$ & $13 \cdot 1^{\mathrm{b}}$ & $1 \cdot 6^{\mathrm{c}}$ & $1 \cdot 45$ & $\mathrm{Fe}$ \\
\hline
\end{tabular}

a, b.e Means in the same row with unlike superscript letters were significantly different $(P<0.05)$.

$\dagger$ Two-way analysis of variance with level of dietary iron $(\mathrm{Fe})$ and period of bile collection $(\mathrm{P})$ as main effects; significant effects $(P<0.05)$.

* For details of diets and procedures, see Table 1 and pp. $888-889$.

periods there was a significant decrease in biliary $\mathrm{Cu}$ concentration with increasing $\mathrm{Fe}$ intake (Table 5).

Fig. 3 illustrates the absolute amounts of $\mathrm{Fe}$ and $\mathrm{Cu}$ excreted in bile by the rats fed on the diets differing in $\mathrm{Fe}$ concentration. Fe excretion was lower in rats given the low-Fe diet than in rats given either the normal or high-Fe diet. Increased concentrations of $\mathrm{Fe}$ in the diet were associated with a marked drop in biliary $\mathrm{Cu}$ excretion. 

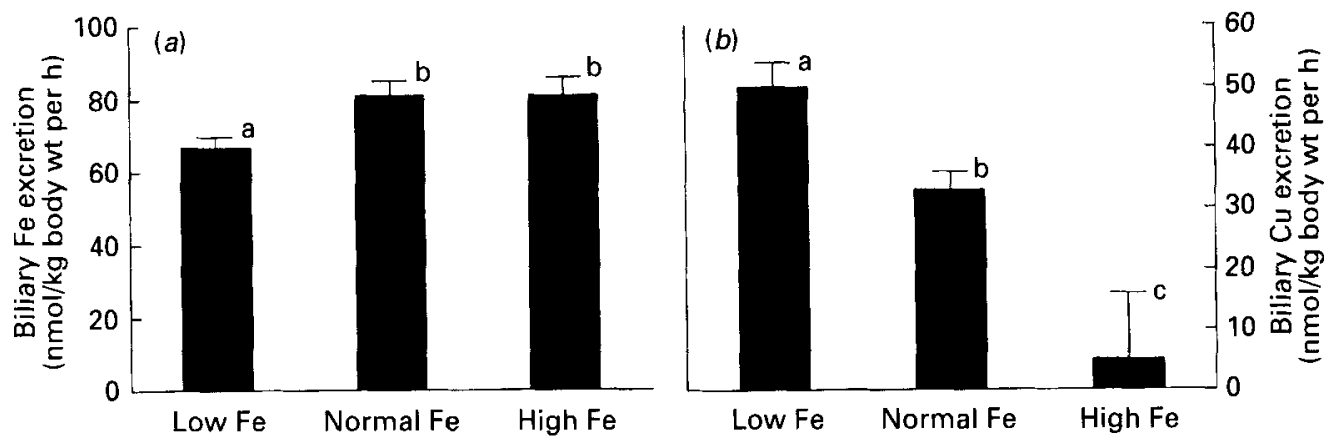

Fig. 3. Biliary excretion of $\mathrm{Fe}(a)$ and $\mathrm{Cu}(b)$ by rats fed on experimental diets containing low, normal or high amounts of Fe for a period of 6 weeks. Bile was collected quantitatively from anaesthetized, cannulated rats for a period of $75 \mathrm{~min}$ immediately after cannulation. Fe and $\mathrm{Cu}$ excretions refer to the $15-75 \mathrm{~min}$ collection period and are expressed as nmol $/ \mathrm{kg}$ body weight per $\mathrm{h}$. Results are expressed as means and SE $(n 15)$; bars within a panel not sharing a common letter were significantly different $(P<0.05)$. For details of diets and procedures see Table 1 and pp. 888-889.

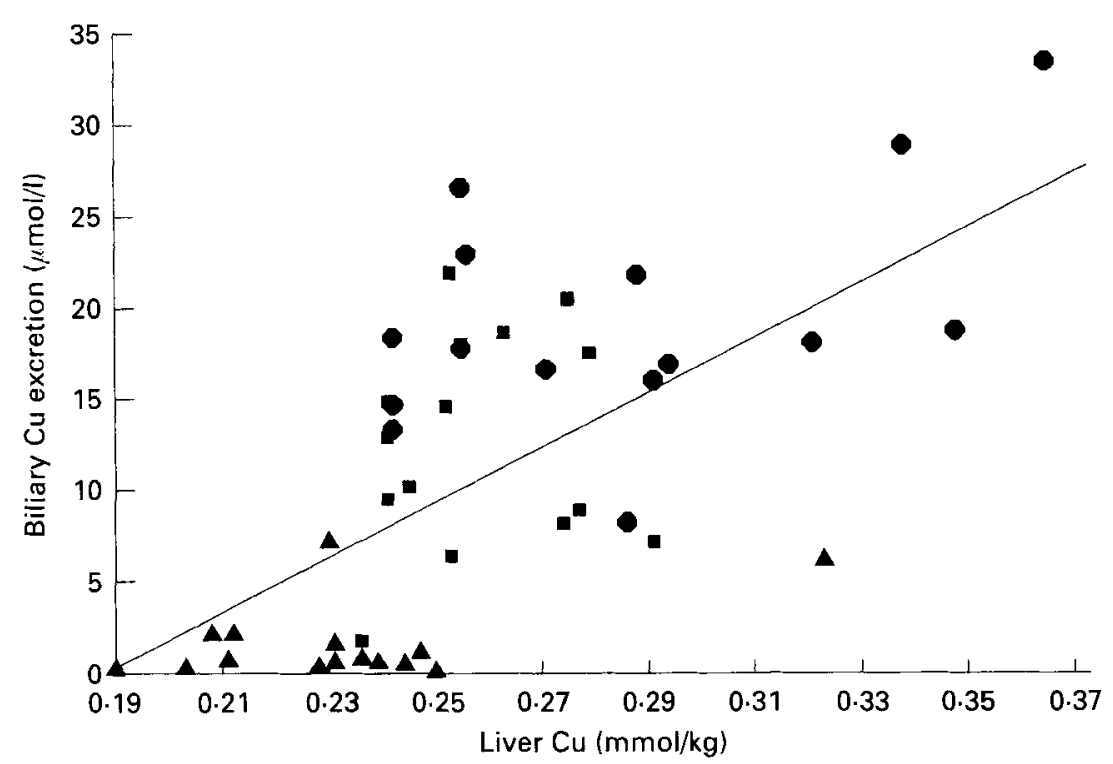

Fig. 4. Relationship between biliary $\mathrm{Cu}$ excretion and hepatic $\mathrm{Cu}$ concentration in individual rats fed on a low-

(A), normal- (U) or high- (O) Fe diet. The regression equation is $y=150 x-28(r 0.63, n 45, P<0.05)$.

For individual rats there was a significant, positive relationship between the concentration of $\mathrm{Cu}$ in liver and that in bile (Fig. 4).

\section{DISCUSSION}

The experimental diets containing different amounts of Fe predictably affected the selected indicators of $\mathrm{Fe}$ status without differently influencing feed intake or body-weight gain. Thus, the low-Fe diet which contained about one fifth of the recommended dietary $\mathrm{Fe}$ concentration for rats (35 mg Fe/kg diet; National Research Council, 1978) lowered blood haemoglobin concentration and packed cell volume and also plasma and organ $\mathrm{Fe}$ concentrations. This agrees with earlier work (Sørensen, 1965; Brouwer et al. 1993). On the 
other hand, Fe loading with a dietary concentration more than ten times the recommended concentration did not alter haemoglobin and packed cell volume, but raised $\mathrm{Fe}$ concentrations in liver and spleen. These findings also support previous studies (Dhur et al. 1989; Kreuzer \& Kirchgessner, 1991).

Modulation of Fe excretion in bile did not appear to be a compensatory mechanism for dealing with Fe loading. Despite the modest rise in liver Fe concentration, the high-Fe diet did not raise biliary $\mathrm{Fe}$ excretion, supporting the view that Fe homeostasis essentially depends on regulating Fe absorption (McCance \& Widdowson, 1937). However, the lowFe diet induced lower rates of biliary Fe excretion than did the other two diets (Fig. 3(a)). This may relate to the decreased hepatic Fe concentrations seen in the rats given the lowFe diet. In any event, our results indicate that decreasing biliary Fe excretion contributes to maintenance of $\mathrm{Fe}$ balance after consumption of low amounts of $\mathrm{Fe}$.

The major objective of the present study was to determine the influence of dietary $\mathrm{Fe}$ concentration on $\mathrm{Cu}$ metabolism. It is clear that increasing intakes of $\mathrm{Fe}$ caused impairment of $\mathrm{Cu}$ status as based on the lowering of $\mathrm{Cu}$ concentrations in plasma and organs. The important finding here is that the antagonistic effect of dietary $\mathrm{Fe}$ on $\mathrm{Cu}$ status can now be explained by the decrease in apparent $\mathrm{Cu}$ absorption. There was an inverse relationship between $\mathrm{Fe}$ intake and $\mathrm{Cu}$ absorption (Fig. 2). Other investigators were not able to demonstrate such an effect in rats (Bremner \& Young, 1981; Johnson \& Hove, 1986). The reason for this discrepancy is not known.

Theoretically, the observed Fe-induced decrease in $\mathrm{Cu}$ absorption must be associated with a decrease in $\mathrm{Cu}$ excretion so that $\mathrm{Cu}$ balance can be attained. Indeed, biliary excretion of $\mathrm{Cu}$ was found to be depressed with higher intakes of Fe (Fig. 3(b)). The rats given the low-Fe diet had an apparent absorption of about $2.28 \mu \mathrm{mol} \mathrm{Cu} / \mathrm{d}(0.90 \times$ intake $)$, and for the rats given the high-Fe diet apparent $\mathrm{Cu}$ absorption equalled $1.64 \mu \mathrm{mol} / \mathrm{d}(0.62 \times$ intake $)$. Based on the data in Fig. 3(b), biliary Cu excretion in rats given the low-Fe diet was in the order of $0.43 \mu \mathrm{mol} / \mathrm{d}$, and in rats given the high-Fe diet it was $0.04 \mu \mathrm{mol} / \mathrm{d}$. Thus these calculations, which should be interpreted cautiously, suggest that the Fe-induced reduction in biliary $\mathrm{Cu}$ excretion may not compensate fully for the decrease in $\mathrm{Cu}$ absorption. This notion is reinforced by the fact that true $\mathrm{Cu}$ absorption will be greater than the calculated values for apparent $\mathrm{Cu}$ absorption. In addition, part of the $\mathrm{Cu}$ excreted with bile will be re-absorbed so that the net loss of $\mathrm{Cu}$ with bile may be less than that calculated. Excretion of $\mathrm{Cu}$ in bile is probably regulated by $\mathrm{Cu}$ concentration in liver. At least for rats given the normal or high-Fe diet, the output of $\mathrm{Cu}$ with bile was directly related to liver $\mathrm{Cu}$ concentration (Fig. 4).

Liver $\mathrm{Cu}$ concentrations were only marginally reduced with increasing Fe intake while plasma and biliary $\mathrm{Cu}$ concentrations, and also plasma ceruloplasmin activities, showed much greater percentage reductions. This could be interpreted to mean that dietary $\mathrm{Fe}$ interferes with $\mathrm{Cu}$ metabolism not only at the absorptive but also at the post-absorptive level. Perhaps an increased $\mathrm{Fe}$ status affects the mobilization of $\mathrm{Cu}$ stores in the liver resulting in depressed incorporation of $\mathrm{Cu}$ into ceruloplasmin and bile fluid.

In summary, increasing $\mathrm{Fe}$ intakes impaired $\mathrm{Cu}$ status in rats. This was probably caused by inhibition of $\mathrm{Cu}$ absorption followed by a decrease in biliary $\mathrm{Cu}$ excretion, but the initial effect of increased $\mathrm{Fe}$ intake on $\mathrm{Cu}$ absorption is not known. In addition, an increased $\mathrm{Fe}$ status could interfere with the mobilization of $\mathrm{Cu}$ stores. The adverse effect of dietary $\mathrm{Fe}$ on $\mathrm{Cu}$ metabolism might be important in man under the extreme condition of a very high $\mathrm{Fe}$ intake combined with a low $\mathrm{Cu}$ intake. Ingestion of $\mathrm{Fe}$ supplements and/or Fe-fortified foods occurs frequently in humans (Ashworth \& March, 1973; Rios et al. 1975; Li et al. 1988), while $\mathrm{Cu}$ intake in humans is considered to be often marginal or even deficient (Guthrie \& Robinson, 1977; Holden et al. 1979). 
S. Y. was the recipient of a fellowship provided by the Cultural Exchange Program between the State Education Commission of The People's Republic of China and The Ministry of Education and Science of The Netherlands, and was supported by The Netherlands Foundation for Nutrition and Health Research.

\section{REFERENCES}

Ashworth, A. \& March, Y. (1973). Iron fortification of dried skim milk and maize-soya-bean-milk mixture (CSM): availability of iron in Jamaican infants. British Journal of Nutrition 30, 577-584.

Bremner, I. \& Price, J. (1985). Effects of dietary iron supplements on copper metabolism in rats. Trace Elements in Man and Animals 5, 374-376.

Bremner, I. \& Young, B. J. (1981). Effect of variation in dietary iron concentration on copper metabolism in rats. Proceedings of the Nutrition Society 40,69A

Bremner, I., Young, B. W. \& Mills, C. F. (1982). The effects of iron and suiphide on copper metabolism in rats. Proceedings of the Nutrition Society 41,82A

Brouwer, I. A., Lemmens, A. G. \& Beynen, A. C. (1993). Dietary fructose $v$, glucose lowers ferrous-iron absorption in rats. British Journal of Nutrition 70, 171-178.

Dhur, A., Galan, P. \& Hercberg, S. (1989). Effects of doses and duration of iron supplement on iron deficiency in rats. Journal of Clinical Biochemistry and Nutrition 7, 193-200.

Fleck, C. \& Barth, A. (1990). Influence of xenobiotics on bile flow and bile composition in rats - methodological approach. Experimental Pathology 39, 175-185.

Guthrie, B. E. \& Robinson, M. F. (1977). Daily intakes of manganese, copper, zinc and cadmium by New Zealand women. British Journal of Nutrition 38, 55-63.

Holden, J. M., Wolf, W. R. \& Mertz, W. (1979). Zinc and copper in self-selected diets. Journal of the American Dietefic Association 75, 23-28.

Humphries, W. R., Phillippo, M., Young, B. W. \& Bremner, I. (1983). The influence of dietary iron and molybdenum on copper metabolism in calves. British Journal of Nutrition 49, 77-86.

Johnson, M. A. \& Hove, S. S. (1986). Development of anemia in copper-deficient rats fed high levels of dietary iron and sucrose. Journal of Nutrition 116, 1225-1238.

Johnson, M. A. \& Murphy, C. L. (1988). Adverse effects of high dietary iron and ascorbic acid on copper status in copper-deficient and copper-adequate rats. American Joumal of Clinical Nutrition 47, 96-101.

Kreuzer, M. \& Kirchgessner, M. (1991). Iron retention in tissues and carcass of rats during growth and under different oral and parenteral supply of iron as Fe(III)-hydroxide-polymaltose. Journal of Animal Physiology and Animal Nutrition 65, 96-109.

Li, T., Wang, W. M. \& Yeung, D. L. (1988). Efficacy of iron fortified infant cereals in the prevention of iron deficiency in infants in China. Nutrition Reports International 37, 695-701.

McCance, R. A. \& Widdowson, E. M. (1937). Absorption and excretion of iron. Lancet ii, 680-684.

National Research Council (1978). Nutrient Requirements of Laboratory Animals. Washington, DC: National Academy of Sciences.

Reichlmayer-Lais, A. M. \& Kirchgessner, M. (1992). Effekte einer steigenden alimentären Fe-Zufuhr auf die scheinbare Verdaulichkeit von $\mathrm{Fe}, \mathrm{Cu}, \mathrm{Zn}$ und $\mathrm{Mn}$ sowie auf die Gehalte dieser Elemente in Leber und Ganzkörper (Effects of an increasing dietary Fe-supply on the apparent digestibility of $\mathrm{Fe}, \mathrm{Cu}, \mathrm{Zn}$ and $\mathrm{Mn}$, and on the amounts of these elements in liver and whole body). Journal of Animal Physiology and Animal Nutrition $67,67-73$.

Rios, E., Hunter, R. E., Cook, J. D., Smith, N. J. \& Finch, C. A. (1975). The absorption of iron as supplements in infant formulas. Paediatrics 55, 686-693.

Smith, C. H. \& Bidlack, W. R. (1980). Interrelationship of dietary ascorbic acid and iron on the tissue distribution of ascorbic acid, iron and copper in female guinea pigs. Journal of Nutrition 110, 1398-1408.

Sørensen, E. W. (1965). Studies on iron absorption. II. Experiments with iron-deficient and non-deficient rats. Acta Medica Scandinavica 178, 385-392.

SPSS Inc. (1988). Statistical Package for the Social Sciences, 3rd ed. Chicago: SPSS

Standish, J. F., Ammerman, C. B., Simpson, C. F., Neal, F. C. \& Palmer, A. Z. (1969). Influence of graded levels of dietary iron, as ferrous sulphate, on performance and tissue mineral composition of steers. Journal of Animal Science 29, 496-503.

Sunderman, F. W. \& Nomoto, S. (1970). Measurement of human serum ceruloplasmin by its p-phenylenediamine oxidase activity. Clinical Chemistry 116, 903-910.

Van den Berg, G. J. \& Beynen, A. C. (1992). Influence of ascorbic acid supplementation on copper metabolism in rats. British Journal of Nutrition 68, 701-715. 